\title{
Effects of Diet and Age on Oxidative Damage Products in Healthy Subjects
}

\author{
M. KRAJČOVIČOVÁ-KUDLÁČKOVÁ, M. VALACHOVIČOVÁ, V. PAUKOVÁ, \\ M. DUŠINSKÁ
}

Slovak Medical University, Bratislava, Slovak Republic

Received March 14, 2007

Accepted May 15, 2007

On-line July 26, 2007

\begin{abstract}
Summary
Damage of molecules as a consequence of oxidative stress has been implicated in the pathogenesis of chronic diseases related to aging. Diet is a key environmental factor affecting the incidence of many chronic diseases. Antioxidant substances in diet enhance the DNA, lipid and protein protection by increasing the scavenging of free radicals. Products of oxidative damage of DNA (DNA strand breaks with oxidized purines or oxidized pyrimidines), lipids (conjugated dienes of fatty acids) and proteins (carbonyls) in relation to nutrition (vegetarian diet vs. non-vegetarian, traditional mixed diet) were measured in young women aged 20-30 years (46 vegetarians, 48 non-vegetarians) vs. older women aged $60-70$ years (33 vegetarians, 34 nonvegetarians). In young subjects, no differences in values of oxidative damage as well as plasma values of antioxidative vitamins ( $C, \beta$-carotene) were observed between vegetarian and non-vegetarian groups. In older vegetarian group significantly reduced values of DNA breaks with oxidized purines, DNA breaks with oxidized pyrimidines and lipid peroxidation and on the other hand, significantly increased plasma values of vitamin $C$ and $\beta$ carotene were found compared to the respective non-vegetarian group. Significant age dependences of measured parameters (increase in all oxidative damage products and decrease in plasma vitamin concentrations in older women) were noted only in non-vegetarians. Vegetarian values of older women vs. young women were similar or non-significantly changed. The results suggest that increase of oxidative damage in aging may be prevented by vegetarian nutrition.
\end{abstract}

\section{Key words}

Oxidative damage $\bullet$ Nutrition $\bullet$ Antioxidative vitamins $\bullet$ Age

\section{Corresponding author}

M. Kudláčková, Slovak Medical University, Limbova 12, 83303

Bratislava, Slovak Republic. E-mail: marica.kudlackova@szu.sk
Oxidative stress has been implicated in the pathogenesis of chronic diseases related to aging such as cancer and cardiovascular disease (Benzie 2000). It was proposed 50 years ago that free radicals are the major factor involved in the aging process (Harman 1956). The main idea was that aging is caused by the accumulation of free radical-elicited oxidative damage to various biological molecules in tissue cells. Miquel (1991) provided first experimental support to this theory in early years by showing that oxidative damage to mitochondrial DNA and lipofuscin pigment formation in animal tissues are concurrently increased during aging. This "mitochondrial theory of aging" emphasized that enhanced production of reactive oxygen species and accumulation of mitochondrial DNA mutations are a contributory factor to human aging (Linnane et al. 1989).

Evidence that diet is a key environmental factor affecting the incidence of many chronic diseases is overwhelming (Block et al. 1992, Gallus et al. 2004, Key et al. 2006). Antioxidant substances in such a diet enhance the DNA, protein and lipid protection by increasing the scavenging of radical oxidative species that occur during metabolic reactions. The lack of balance between the amount of "unhealthy" and "healthy" food leads to the accumulation of unrepaired damage, initiating DNA instability and inducing cancer development (Kapiszewska 2006).

The main goal of this study was to assess the products of oxidative damage to DNA, lipids and proteins in relation to nutrition and age. Here were compare two nutritional regimens: a vegetarian diet with predominance of plant food with consumption of dairy products, eggs as 
well as $\leq 2$ times monthly consumption of white meat (poultry or fish) vs. a non-vegetarian traditional mixed diet (general population). The other comparison was young vs. older subjects under the condition of a vegetarian nutrition and a traditional non-vegetarian nutrition. Randomly selected group of 161 adult nonsmoking women from the same region (Bratislava and surroundings) was divided into four groups: vegetarian young women aged 20-30 years $(n=46)$, non-vegetarian young women aged 20-30 years $(n=48)$, vegetarian older women aged $60-70$ years $(n=33)$ and non-vegetarian older women aged 60-70 years $(n=34)$. The probands have an approximately similar physical activity (no sports). The group characteristics are presented in Table 1. Plasma concentrations of vitamins C, E, A and $\beta$-carotene were detected by HPLC (Lee et al. 1992, Cerhata et al. 1994). EDTA was used as an anticoagulant. The alkaline comet assay modified with lesion-specific enzymes was used for detection of DNA strand breaks, oxidized purines and oxidized pyrimidines in isolated lymphocytes (Collins et al. 1996). The plasma concentrations of conjugated dienes of fatty acids and protein carbonyls were measured by spectrophotometric methods (Recknagel and Glende 1984, Levine et al. 1990). The intake of vitamins, mineral and trace elements only in natural form was considered (no supplementation).

Values of oxidative damage products as well as plasma antioxidative vitamins are shown in Table 1. In groups of young women, no differences in values of oxidative damage to DNA, lipids and proteins were observed between vegetarians and non-vegetarians. The plasma values of antioxidative vitamins also were similar in both nutritional groups. The significantly reduced values of DNA breaks with oxidized purines, DNA breaks with oxidized pyrimidines as well as lipid peroxidation product were found in older vegetarian group compared to older non-vegetarians. Older vegetarians have the significantly increased plasma values of vitamin $C$ and $\beta$-carotene than older nonvegetarians (Table 1 ).

Current knowledge of nutrition suggests that regular and sufficient consumption of fruit and vegetables, whole grain products, grain sprouts, pulses, plant oils and oil seeds together with healthy life style protect against degenerative diseases (Rajaram and Sabaté 2000, Krajčovičová-Kudláčková 2005, Key et al. 2006). These food commodities are crucial components of vegetarian diets. In previous studies we found significantly reduced values of DNA breaks with oxidized purines and lipid peroxidation products in small group of 24 vegetarians aged 20-69 years in comparison to 24 non-vegetarians of the same age range (Krajčovičová-Kudláčková and Dušinská 2004, Krajčovičová-Kudláčková et al. 2004). The inverse relationships between DNA breaks with oxidized purines and plasma vitamin $\mathrm{C}$ or $\beta$-carotene concentrations as well as between plasma values of conjugated dienes and vitamins $\mathrm{C}, \mathrm{E}$ or $\beta$-carotene were recorded. Vegetarian DNA breaks as well as DNA breaks with oxidized pyrimidines were non-significantly reduced. In other our study were estimated products of oxidative damage to DNA, lipids and proteins in dependence on different vitamin C plasma concentration (KrajčovičováKudláčková et al. 2006). In group of general population under condition of protective plasma vitamin concentration ( $>50 \mathrm{mmol} / \mathrm{l})$ significantly lower values of all oxidative damage products were found in comparison with the vitamin C-deficient group $(<50 \mathrm{mmol} / \mathrm{l})$. The young women in present study have similar values of body mass index and plasma antioxidative vitamins. These results suggest an approximately similar consumption of protective food in young vegetarians and non-vegetarians. This conclusion is supported by optimal plasma concentrations (with high antioxidative effect) of vitamin $\mathrm{C}$ and $\beta$-carotene as main vitamins derived from fruit and vegetables. The significantly higher values of vitamins (C, $\beta$-carotene) and significantly reduced values of products of oxidative damage (DNA breaks with oxidized purines, DNA breaks with oxidized pyrimidines, conjugated dienes of fatty acids, protein carbonyls) in older vegetarian women than in older non-vegetarian women suggest an incorrect composition of nonvegetarian diet and, on the other hand, a protective effect of vegetarian diet against age-related degenerative diseases.

A significant age dependence (the increase in older subjects) of DNA damage with oxidized purines, DNA damage with oxidized pyrimidines, lipid peroxidation and protein oxidation was found in nonvegetarian women. The vegetarian values were ageindependent. Plasma values of antioxidative vitamins, vitamin $C$ and $\beta$-carotene significantly decreased in older non-vegetarian women. In vegetarian groups, these vitamin values were similar in young and older subjects. Age-dependent nutrition changes in case of vitamin A were not observed (Table 1). The significantly increased plasma values of lipid soluble vitamin E in older subjects 
Table 1. Products of DNA, protein, lipid oxidative damage and concentrations of antioxidative vitamins in young and older vegetarians and non-vegetarians.

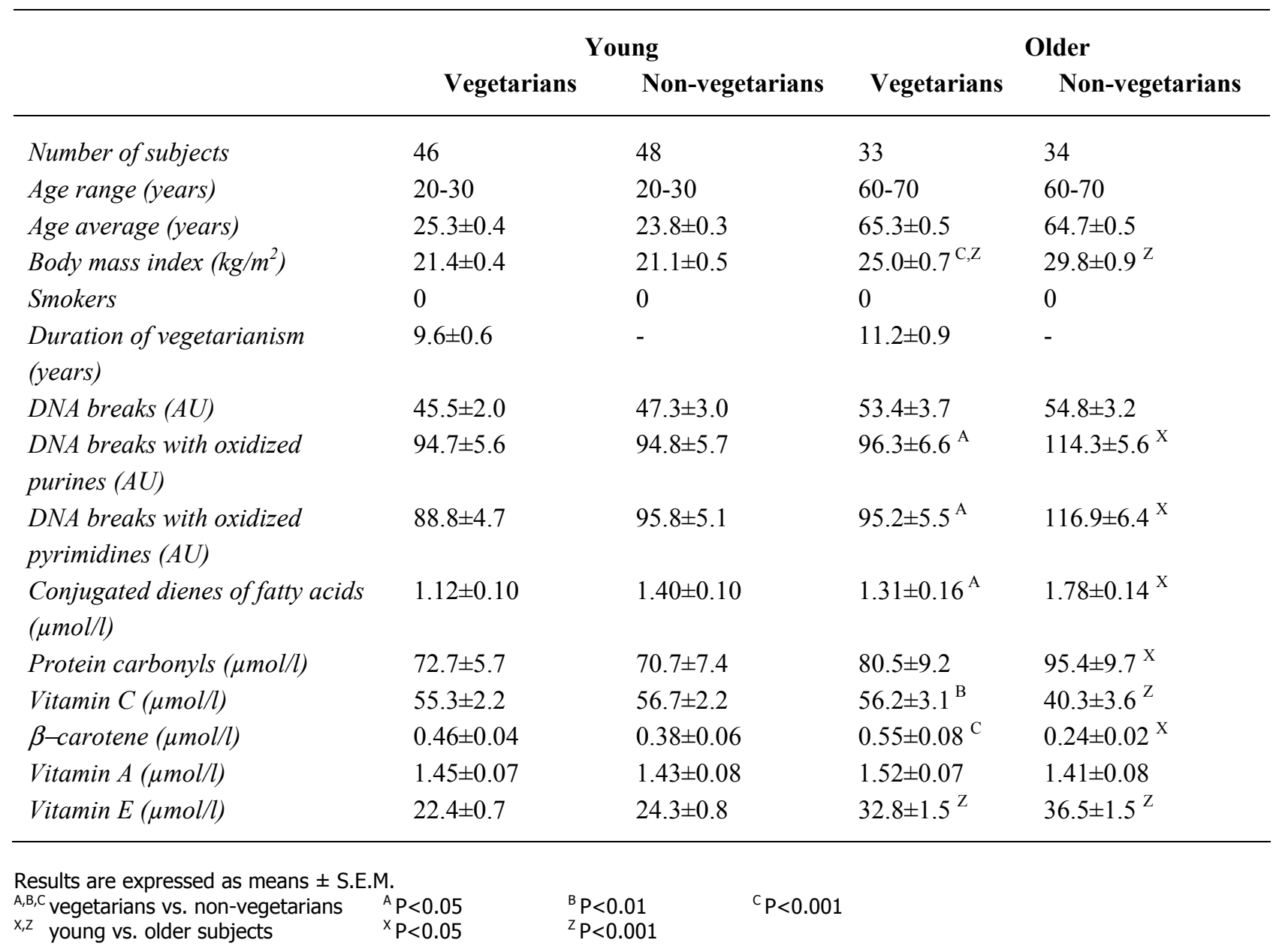

on both diets compared to young subjects are a consequence of its accumulation at higher body fat content (Table 1). This assumption is supported by increased values of body mass index in older subjects of both nutritional regimens (Table 1). The significantly higher value of body mass index in older non-vegetarians than in older vegetarians (overweight upper limit obesity beginning) confirms the incorrect composition of non-vegetarian diet. The same conclusions concerning body mass index and incorrect nutrition in general population were obtained in our previous epidemiological studies (Krajčovičová-Kudláčková et al. 2005).

Oxidative DNA damage may be important in mutagenic, carcinogenic, and aging processes. Although it is plausible that antioxidant vitamins may reduce oxidative DNA damage, evidences for favorable effects of vitamin supplements in human studies are partly inconsistent (Moller and Loft 2006). It is evident that antioxidant intake through consumption of antioxidantrich foods was more effective at lowering DNA damage than supplementation with single antioxidants. The benefits of fruit and vegetable intake became evident with the consumption being at least three servings/day (Huang et al. 2000). Supplementation of diet with $500 \mathrm{mg}$ of vitamin $\mathrm{C}$ daily and $400 \mathrm{IU} \mathrm{d}$ - $\alpha$-tocopherylacetate/day had no significant main effect or interaction effect on oxidative DNA damage as measured by urinary 8hydroxy-2'-deoxyguanosine in non-smoking adults (Huang et al. 2000). On the other hand, Moller et al. (2004) found that long-term vitamin C supplementation at high dose $500 \mathrm{mg}$ together with vitamin $\mathrm{E}$ in moderate dose $182 \mathrm{mg}$ decreased the steady-state level of oxidative DNA damage in mononuclear blood cells of smokers. Various aspects of the Mediterranean diet or the vegetarian diet are considered favorable with regard to cancer risk (Rajaram and Sabaté 2000, Gallus et al. 2004). For most epithelial cancers, the risk decreased with increasing vegetable and fruit consumption, with odds ratios between 0.3 and 0.7 for the highest compared to the lowest tertile. Subjects reporting frequent red meat intake showed odds ratios above unity for several common neoplasms. Whole grain food intake was related 
to reduced risk of several types of cancer, particularly of the upper digestive tract, probably on account of its high fiber content. Intake of legumes was inversely associated with risk of colon cancer and pancreatic cancer (Fraser 1999). Several phytochemicals such as flavonoids, isothiocyanates and allylsulfides derived from fruit and vegetables are potent modulators of the enzyme system responsible for metabolizing carcinogens (Rajaram and Sabaté 2000). Antioxidant vitamins $\mathrm{C}$ and $\mathrm{E}$ and polyphenols inhibit formation of $\mathrm{N}$-nitroso compounds, which are potential carcinogens (Bartsch and Frank 1996). Phytochemicals in whole grains and legumes have the ability to block initial DNA damage and suppress post-initiation, which in turn can halt the carcinogenic process. The increased glucagon activity as a consequence of higher intake of arginine and pyruvigenic amino acids from plant protein sources may lead to a decrease in insulin-like growth factor activity that can be expected to retard cancer development (McCarty 1997).
Our previous studies have shown that vegetarian consumption of protective food is significantly higher in comparison to non-vegetarians (fruit 463 vs. $176 \mathrm{~g} /$ day, vegetables 195 vs. 62 g, whole grain products 242 vs. 65 g, nuts 29 vs. 7 g, plant oils 63 vs. 32 g, legumes 38 vs. 6 g) (Krajčovičová-Kudláčková et al. 2004).

It is well known that oxidative damage to tissue macromolecules increases during aging (Barja 2002). The results of present study suggest that increase of oxidative damage in aging may be prevented by vegetarian nutrition.

\section{Conflict of Interest}

There is no conflict of interest.

\section{Acknowledgements}

This work was supported by Research and Development Support Agency under the contract No. APVT-21-17704.

\section{References}

BARJA G: Endogenous oxidative stress, relation to aging, longevity and caloric restriction. Ageing Res Rev 1: 397-411, 2002.

BARTSCH H, FRANK N: Blocking the endogenous formation of N-nitroso compounds and related carcinogens. IARC Sci Publ 139: 189-193, 1996.

BENZIE IF: Evolution of antioxidant defence mechanisms. Eur J Nutr 39: 53-61, 2000.

BLOCK G, PATTERSON B, SUBAR A: Fruit, vegetables, and cancer prevention, a review of the epidemiological evidence. Nutr Cancer 18: 1-29, 1992.

CERHATA D, BAUEROVA A, GINTER E: Ascorbic acid determination in serum by high performance liquid chromatography and its correlation with spectrophotometric determination. Ces Slov Farm 43: 166-168, 1994.

COLLINS AR, DUŠINSKÁ M, GEDIK CM, ŠTĚTINA R: Oxidative damage to DNA, do we have a reliable biomarker? Environ Health Perspect 104: 465-469, 1996.

FRASER GE: Associations between diet and cancer, ischemic heart disease, and all-cause mortality in non-Hispanic white California Seventh-day Adventists. Am J Clin Nutr 70(3 Suppl): 532S-538S, 1999.

GALLUS S, BOSETTI C, LA VECCHIA C: Mediterranean diet and cancer risk. Eur J Cancer Prev 13: 447-452, 2004.

HARMAN D: Aging, theory based on free radical and radiation chemistry. J Gerontol 11: 298-300, 1956.

HUANG HY, HELZLSOUER KJ, APPEL LJ: The effects of vitamin C and vitamin E on oxidative DNA damage, results from a randomized controlled trial. Cancer Epidemiol Biomarkers Prev 9: 647-652, 2000.

KAPISZEWSKA M: A vegetable to meat consumption ratio as a relevant factor determining cancer preventive diet. The Mediterranean versus other European countries. Forum Nutr 59: 130-153, 2006.

KEY TJ, APPLEBY PN, ROSELL MS: Health effects of vegetarian and vegan diets. Proc Nutr Soc 65: 35-41, 2006.

KRAJČOVIČOVÁ-KUDLÁČKOVÁ M: Health benefits of plant food. Klin Biochem Metab 13: 168-171, 2005.

KRAJČOVIČOVÁ-KUDLÁČKOVÁ M, DUŠINSKÁ M: Oxidative DNA damage in relation to nutrition. Neoplasma 51: 30-33, 2004.

KRAJČOVIČOVÁ-KUDLÁČKOVÁ M, DUŠINSKÁ M, VALACHOVIČOVÁ M, BLAŽÍČEK P, PAUKOVÁ V: Products of DNA, protein and lipid oxidative damage in relation to vitamin C plasma concentration. Physiol Res 55: 227-231, 2006. 
KRAJČOVIČOVÁ-KUDLÁČKOVÁ M, SPUSTOVÁ V, PAUKOVÁ V: Lipid peroxidation and nutrition. Physiol Res 53: 219-224, 2004.

KRAJČOVIČOVÁ-KUDLÁČKOVÁ M, SPUSTOVÁ V, BLAŽÍČEK P, VALACHOVIČOVÁ M: Cardiovascular risk factors in two nutritional groups of elderly population. Cor Vasa 47: 354-358, 2005.

LEE BL, CHUA SC, ONG HY, ONG CN: High performance liquid chromatographic method for routine determination of vitamins A and E, and beta-carotene in plasma. J Chromatogr 581: 41-43, 1992.

LEVINE RL, GARLAND D, OLIVER CN, AMICI A, CLIMENT I, BENZ AG, AHN BW, SHALTIEL S, STADTMAN ER: Determination of carbonyl content in oxidatively modified proteins. Methods Enzymol 186: 464-479, 1990.

LINNANE AW, MARZUKI S, OZAWA T, TANAKA M: Mitochondrial DNA mutations as an important contributor to ageing and degenerative disease. Lancet 1: 642-645, 1989.

MIQUEL J: An integrated theory of aging as the result of mitochondrial DNA mutation in differentiated cells. Arch Gerontol Geriatr 12: 99-117, 1991.

MCCARTY MF: Up-regulation of IGF binding protein-1 as an anticarcinogenic strategy, relevance to caloric restriction, exercise, and insulin sensitivity. Med Hypotheses 48: 297-308, 1997.

MOLLER P, LOFT S: Dietary antioxidants and beneficial effect on oxidatively damaged DNA. Free Radic Biol Med 41: 388-415, 2006.

MOLLER P, VISCOVICH M, LYKKESFELDT J, LOFT S, JENSEN A, POULSEN HE: Vitamin C supplementation decreases oxidative DNA damage in mononuclear blood cells of smokers. Eur J Nutr 43: 267-274, 2004.

RAJARAM S, SABATÉ J: Health benefits of a vegetarian diet. Nutrition 16: 531-533, 2000.

RECKNAGEL E, GLENDE EA: Spectrophotometric detection of lipid conjugated dienes. Methods Enzymol 105: 331$337,1984$. 